\title{
Esofagitis Refluks Pada Anak
}

\author{
Badriul Hegar, R. Lia Mulyani
}

Esofagitis refluks adalah proses inflamasi pada esofagus akibat refluks gastroesofagus. Toksisitas isi refluks, frekuensi, durasi episode refluks, dan resistensi esofagus terhadap isi refluks merupakan faktor yang berperan terhadap kejadian esofagitis. Gejala klinis esofagitis refluks tidak spesifik. Pada bayi sering terlihat muntah disertai gejala klinis iritabel, tidur tidak nyaman, menolak makan, dan gagal tumbuh, sedangkan pada anak yang lebih besar didapatkan keluhan heartburn dan nyeri epigastrium. Esofagitis tersebar secara 'patchy' dan tidak merata sehingga ketelitian pemeriksaan sangat diperlukan. Secara makroskopis mukosa esofagus dapat terlihat hiperemis, erosi, atau ulkus, sedangkan pada patologi anatomi terlihat gambaran hiperplasia membran basal dengan papila yang memanjang. Antagonis reseptor $\mathrm{H} 2$ dan inhibitor pompa proton (IPP) telah digunakan secara luas untuk terapi esofagitis. Efek jangka pendek, jangka panjang, dan pencegahan relaps obat-obat tersebut memperlihatkan hasil yang memuaskan, walaupun beberapa data menunjukkan keunggulan IPP dibanding antagonis reseptor $\mathrm{H} 2$.

Kata kunci: refluks gastroesofagus, esofagitis, antagonis reseptor $\mathrm{H} 2$, inhibitor pompa propton

$\sigma^{\circ}$ ofagitis refluks merupakan proses inflamasi epitel esofagus yang dapat disebabkan oleh berbagai faktor. Pada anak, esofagitis dapat terjadi akibat refluks gastroesofagus (RGE), infeksi (bakteri, virus dan jamur), atau bahan korosif. Esofagitis akibat RGE dikenal sebagai esofagitis refluks, merupakan bentuk penyakit refluks gastroesofagus (PRGE) dan penyebab esofagitis tersering pada anak. ${ }^{1,2}$

Esofagitis refluks melibatkan berbagai proses yang mengakibatkan tidak berfungsinya mekanisme yang mencegah RGE dan mekanisme yang membersihkan

\footnotetext{
Alamat korespondensi:

Dr. Badriul Hegar, Sp.A.(K) Divisi Gastroenterologi. Departemen Ilmu Kesehatan Anak FKUI-RSCM. Jl. Salemba no. 6, Jakarta 10430. Telepon: 021-3915665. Fax.021-390 7743.
}

esofagus dari bahan toksik. ${ }^{2}$ Toksisitas isi refluks (seperti asam, pepsin, empedu), frekuensi dan durasi episode refluks, serta resistensi esofagus terhadap isi refluks merupakan faktor yang berperan terhadap kejadian esofagitis. ${ }^{3-5}$

Refluks gastroesofagus terjadi akibat aliran balik isi lambung ke dalam esofagus yang terjadi secara involunter. Keadaan ini merupakan fenomena fisiologis pada bayi yang bermanifestasi klinis sebagai regurgitasi. ${ }^{4}$ Diperlukan pemeriksaan penunjang untuk membuktikan adanya RGE dan kerusakan mukosa esofagus akibat RGE.

Pada beberapa individu, esofagitis refluks dapat merupakan suatu keadaan yang dialami seumur hidup dan dimulai sejak masa anak. Oleh karena itu, diagnosis dini dan terapi yang tepat pada masa anak sangat diperlukan untuk menghasilkan kondisi dan kualitas hidup yang lebih baik pada masa remaja dan dewasa. ${ }^{6}$ 


\section{Epidemiologi}

Regurgitasi merupakan gejala klinis yang paling sering ditemukan pada bayi yang mengalami RGE. Regurgitasi $1-4$ kali setiap harinya ditemukan pada $70 \%$ bayi berumur $3-4$ bulan, 5\%-12\% bayi berumur 9-12 bulan, dan $0-3 \%$ anak berumur 2 tahun..$^{6-8,9}$ Esofagitis refluks ditemukan pada 15\%-62\% anak dengan gejala PRGE dan prevalensinya meningkat sesuai dengan bertambahnya usia. ${ }^{10}$ El-Serag dkk. melaporkan prevalens esofagitis refluks $27 \%$ pada usia 1,5-5 tahun, $31 \%$ pada usia $5-10$ tahun, dan $58 \%$ pada usia $10-15$ tahun. Prevalens tertinggi ditemukan pada usia 15-25 tahun yaitu $91 \% .{ }^{11}$ Esofagus Barrett ditemukan pada 0,1\%-3\% anak dan diperlukan tindakan bedah pada 6\%-13\% kasus. ${ }^{10}$ Berdasarkan laporan orangtua, keluhan heartburn ditemukan pada $1,8 \%$ anak berusia 3-9 tahun dan 3,5\% anak berusia 10-17 tahun, sedangkan nyeri epigastrium ditemukan pada 7,2\% anak berusia 3-9 tahun dan 3\% anak usia 10-17 tahun. ${ }^{12}$

\section{Definisi}

Esofagitis refluks adalah proses inflamasi pada esofagus yang terjadi akibat RGE. ${ }^{13}$ Proses inflamasi tersebut dapat disertai perubahan pada mukosa esofagus seperti erosi atau hiperplasi epitel. ${ }^{14}$ Refluks gastroesofagus sendiri didefinisikan sebagai masuknya isi lambung ke dalam esofagus yang berlangsung secara involunter. Isi lambung tersebut dapat berupa saliva, makanan, minuman, sekresi lambung atau sekresi pankreas dan empedu yang terlebih dahulu masuk ke dalam lambung (refluks duodenogaster). ${ }^{4,5,14}$ Istilah regurgitasi digunakan bila isi refluks dikeluarkan melalui mulut secara pasif (tanpa adanya upaya dari tubuh). ${ }^{4}$

\section{Patofisiologi}

Konsep PRGE pada awalnya berkaitan dengan aktivitas cairan lambung pada mukosa esofagus, selanjutnya dihubungkan dengan kejadian hiatus hernia, dan lemahnya (atoni) spingter esofagus bagian bawah. ${ }^{14}$ Konsep terakhir yang disepakati adalah esofagitis refluks tidak disebabkan oleh hanya 1 faktor, melainkan oleh berbagai faktor yang saling berhubungan. ${ }^{2,13}$ Esofagitis refluks terjadi bila terdapat ketidakseimbangan antara faktor yang menyebabkan RGE (faktor agresif) dan faktor yang mencegah RGE (faktor pertahanan). ${ }^{4,15}$ Faktorfaktor tersebut, adalah:

\section{Spingter esofagus bagian bawah}

Spingter esofagus bagian bawah (SEB) merupakan salah satu barier anti refluks yang memiliki 2 komponen mekanisme pertahanan, yaitu (1) SEB intrinsik berupa otot polos esofagus dan (2) SEB ekstinsik berupa lengkung diafragma. ${ }^{16,17}$ Sebagian SEB berada intraabdomen dan sebagian lagi intratoraks. Keduanya membentuk hiatus esofagus dan bekerja sama menghasilkan tekanan SEB yang merupakan mekanisme pertahanan penting terhadap RGE. ${ }^{2,15,16}$

Selama proses menelan, SEB akan relaksasi selama 3-10 detik dengan tekanan terendah (minimal 2 $\mathrm{mmHg}$ di atas tekanan intragastrik) untuk memberikan jalan kepada bolus makanan masuk ke dalam lambung. Selanjutnya, SEB akan mencegah refluks dengan cara mempertahankan tekanan saat istirahat (resting pressure) sebesar $5-10 \mathrm{mmHg}$ lebih tinggi dibanding tekanan lintragastrik. ${ }^{16}$ Bila terdapat peningkatan tekanan intra-abdomen secara mendadak pada saat batuk, bersin atau distensi lambung, maka tekanan SEB akan lebih ditingkatkan agar mencegah refluks. Spingter esofagus bagian bawah yang kompeten mampu menjaga tekanannya agar selalu berada di atas tekanan intragastrik. ${ }^{17}$

Disfungsi SEB akan menyebabkan kemampuan sfingter mengatur tekanannya terganggu, sehingga lebih mudah terjadi refluks. Tekanan SEB pada anak dengan PRGE dilaporkan bervariasi antara 4-25 $\mathrm{mmHg}$ (sebagian besar lebih dari $10 \mathrm{mmHg}$ ) atau 6$15 \mathrm{mmHg}$ lebih rendah dibanding anak normal. Tekanan SEB menurun seiring dengan meningkatnya derajat penyakit. ${ }^{15}$

\section{Transient lower esophageal relaxation}

Transient lower esophageal relaxation (TLESR) adalah relaksasi SEB yang tidak berhubungan dengan proses menelan dan berlangusng lebih lama dari biasanya (lebih dari 10 detik). ${ }^{15-17}$ TLESR dikontrol melalui refleks vago-vagal; sisi aferen diatur oleh mekanoreseptor pada dinding proksimal lambung, sedangkan sisi eferen diatur oleh batang otak. ${ }^{16}$ TLESR terjadi 
bersamaan dengan inhibisi lengkung diafragma dan badan esofagus sehingga mempermudah aliran balik isi lambung ke dalam esofagus. ${ }^{15,16}$ Keadaan ini sering terjadi setelah makan dan dipicu oleh distensi lambung, sehingga adanya gangguan pengosongan lambung akan meningkatkan frekuensi TLESR. Saat terjadi TLESR, tekanan SEB turun menuju nol sehingga tidak berfungsi sebagai barier anti refluks. Dilaporkan bahwa 70\%-90\% episode RGE pada anak dengan PRGE berhubungan dengan TLESR. ${ }^{16}$ Pada laporan lain didapatkan 100\% TLESR pada RGE fisiologi dan 66\% TLESR pada esofagitis berat, sedangkan pada akalasia tidak ditemukan TLESR. Walaupun masih perlu pengkajian lebih lanjut, berdasarkan pengamatan tersebut dapat disimpulkan sementara bahwa TLESR pada RGE patologi mungkin berperan sebagai mekanisme kontrol. Beberapa keadaan lain seperti pemakaian intubasi, anastesi, tidur, dan stres dilaporkan juga dapat meningkatkan frekuensi TLESR. ${ }^{4,15-17}$

\section{Klirens esofagus}

Klirens esofagus terjadi setelah episode refluks untuk mengurangi durasi kontak antara isi lambung dengan epitel esofagus. Pada keadaan normal, esofagus membersihkan asam dengan 4 mekanisme, yaitu gravitasi, peristaltik, saliva dan produksi bikarbonat instrinsik esofagus. Saat bolus asam masuk ke dalam esofagus, sebagian besar asam tersebut akan dibersihkan oleh gravitasi dan pristaltik. Sisa asam akan dinetralkan oleh saliva (bersifat alkali) yang tertelan dan bikarbonat yang diproduksi oleh kelenjar esofagus. ${ }^{2,4,17}$

Refluks gastroesofagus yang terjadi saat tidur dapat merusak mukosa esofagus karena pada posisi terlentang peran gravitasi berkurang dan selama tidur tidak tejadi penelanan saliva sehingga mengurangi klirens esofagus. Disamping itu, hiatus hernia juga mengganggu klirens esofagus. ${ }^{2,17}$

Keterlambatan klirens refluks asam berhubungan dengan tingkat keparahan PRGE., ${ }^{216}$ Pada esofagitis refluks terdapat penurunan amplitudo gelombang peristaltik sebesar 30\%-50\%, yang menandakan adanya gangguan pada kontraksi esofagus. ${ }^{16}$

\section{Pertahanan esofagus}

Esofagitis timbul akibat kontak antara zat toksik yang terdapat pada isi refluks dengan mukosa esofagus dalam kurun waktu yang cukup untuk mengalahkan pertahanan esofagus. ${ }^{2}$ Pertahanan esofagus ditentukan oleh ketahanan mukosa dalam mengurangi kerusakan selama terjadi kontak dengan isi lumen yang toksik. Mekanisme pertahanan esofagus dapat dikelompokan menjadi pertahanan pre-epitelial, epitelial, post epitelial, dan perbaikan jaringan. ${ }^{2,17,18}$

\section{Pertahanan pre-epitelial}

Mekanisme ini mencegah kontak langsung ion $\mathrm{H}^{+}$ dalam lumen esofagus dengan sel epitel skuamosa. Komponen yang berperan dalam mekanisme ini adalah lapisan mukus, unstirred water layer, dan lapisan ion bikarbonat yang terdapat pada permukaan mukosa. Asam dinetralisasi oleh $\mathrm{HCO}_{3}$ - di lapisan mukus dan lama kontak dengan asam dipersingkat oleh unstirred water. ${ }^{2,17,18}$

\section{Pertahanan epitelial}

Mekanisme ini mencegah masuknya ion $\mathrm{H}^{+}$ke dalam sel dan mengeleminasi ion $\mathrm{H}^{+}$yang sudah masuk ke dalam sel. Agar dapat masuk ke dalam sel, ion $\mathrm{H}^{+}$ harus melalui membran sel atau ruang interselular sehingga pergerakan ion $\mathrm{H}^{+}$dibatasi oleh tight junction dan materi interselular (lipid dan musin). Membran sel dan kompleks junction interseluler merupakan barier utama terhadap ion $\mathrm{H}^{+}$. Ion $\mathrm{H}^{+}$yang melalui sel epitel akan dinetralisir oleh protein intraseluler, fosfat dan bikarbonat. Membran sel memiliki sistem transpor ion yang mengatur pertukaran $\mathrm{Na}^{+} / \mathrm{H}^{+}$dan $\mathrm{Cl}^{-} \mathrm{HCO}_{3}{ }^{2,17,18}$

\section{Pertahanan post epitelial}

Aliran darah ke esofagus akan meningkat pada saat esofagus berkontak dengan bahan toksik. ${ }^{18}$ Suplai darah ke esofagus dapat memberikan efek perlindungan dengan cara (1) memindahkan bahan toksik $\left(\mathrm{CO}_{2}\right.$ dan ion $\mathrm{H}^{+}$) keluar dari sel epitel dan (2) mensuplai bikarbonat, oksigen dan nutrisi ke ruang interselular untuk menetralisir asam..$^{2,18,19}$

\section{Perbaikan jaringan}

Sel epitel esofagus dapat memperbaiki kerusakan jaringan. Proses perbaikan jaringan esofagus lebih cepat 
dibanding mukosa lambung. ${ }^{2,18}$ Faktor yang berperan dalam proses perbaikan epitel antara lain epidermal growth factor (EGF), hepatocyte growth factor (HGF) dan nitrit oksida. Kelenjar saliva mensekresi EGF dengan kadar tinggi sehingga dapat menstimulasi sintesis DNA yang mempunyai efek ploriferatif yang besar. Hepatocyte growth factor menstimulasi pertumbuhan beberapa tipe sel epitel dengan aktivitas perbaikan sel lebih besar dibanding EGF. Nitrit oksida berperan mempertahankan mikrosirkulasi esofagus. ${ }^{19}$ Pada esofagitis refuks terjadi replikasi epitel esofagus yang cepat sehingga akan ditemukan hiperplasia sel basal. $^{2}$

\section{Isi lambung}

Refluks gastroesofagus akan menyebabkan kerusakan pada esofagus bila isi refluks bersifat kaustik terhadap mukosa esofagus. Isi lambung yang berpotensi sebagai kaustik adalah asam, pepsin, empedu dan enzim pankreas (tripsin, lipase). ${ }^{2,17} \mathrm{Pada} \mathrm{pH}$ rendah atau suasana asam, ion $\mathrm{H}^{+}$merupakan penyebab kerusakan mukosa esofagus yang sangat bergantung kepada konsentrasi $(\mathrm{pH})$ dan lama paparan. Kerusakan mukosa esofagus akan terlihat bila $\mathrm{pH}$ lumen esofagus $<2$ atau terdapat pepsin atau empedu di dalam isi refluks. ${ }^{2,18}$ Kombinasi refluks asam dan empedu akan menyebabkan kerusakan mukosa esofagus (esofagitis) yang berat, sedangkan refluks asam saja atau refluks empedu saja umumnya menyebabkan esofagitis ringan-sedang. ${ }^{19}$

\section{Hiatus hernia}

Sebagian besar pasien dengan PRGE berat memiliki hiatus hernia. Hiatus hernia merupakan protusi esofagogastric junction dan sebagian fundus gaster melewati hiatus lengkung diafragma ke arah dada. Timbulnya RGE diinduksi oleh peningkatan tekanan intraabdomen secara tiba-tiba dan berkorelasi dengan ukuran hiatus hernia. ${ }^{2,15,17}$

Tekanan SEB pada hiatus hernia rendah sehingga merupakan predisposisi terjadinya RGE. Hiatus hernia yang besar akan mengganggu mekanisme antirefluks ekstrasfingter akibat adanya gangguan penjepitan lengkung diafragma saat inspirasi. Pada hiatus hernia terbentuk kantung lambung di sekitar lengkung diafragma yang berfungsi sebagai reservoir isi refluks. ${ }^{2,15,17}$

\section{Gejala klinis}

Penyakit RGE memiliki spektrum gejala klinis yang luas dan berbeda untuk setiap kelompok umurnya (Tabel 1). Regurgitasi, nausea dan muntah merupakan gejala spesifik yang paling sering terlihat pada bayi, sedangkan pada anak yang lebih besar didapatkan keluhan disfagia, heartburn, dan nyeri epigastrium. Pada esofagitis berat dapat terjadi hematemesis dan melena. ${ }^{3,5,10,20}$

\section{Pemeriksaan penunjang}

Pemeriksaan penunjang bertujuan untuk memastikan adanya RGE dan kerusakan mukosa esofagus akibat RGE. Berbagai pemeriksaan penunjang pernah dilaporkan sebagai alat bantu diagnosis esofagitis refluks, walaupun demikian beberapa pemeriksaan tersebut mempunyai keterbatasan sebagai alat diagnostik. Pemeriksaan penunjang yang tepat sangat diperlukan untuk membantu menegakkan diagnosis esofagitis refluks.

Barium meal dan ultrasonografi dapat mendeteksi RGE tetapi tidak dapat mendeteksi esofagitis refluks. Selain itu, nilai diagnostik kedua pemeriksaan tersebut rendah karena hanya dapat menilai RGE postprandial sedangkan refluks yang terjadi postprandial adalah fisiologis. ${ }^{20-23}$ Demikian pula dengan skintigrafi, meskipun pemeriksaan ini dapat melihat klirens esofagus dan aspirasi. ${ }^{15,22}$ Pemeriksaan manometri digunakan untuk mengetahui tekanan SEB pada keadaan istirahat dan peristaltik serta memprediksi klirens abnormal. ${ }^{20,24}$ Manometri cukup invasif terutama pada bayi dan anak kecil, sehingga pemeriksaan ini lebih sering digunakan untuk penelitian dibanding sebagai prosedur diagnostik standar. Pemeriksaan penunjang yang digunakan sebagai alat diagnostik esofagitis refluks, yaitu:

\section{Pemantauan $\mathrm{pH}$ esofagus}

Meskipun masih terdapat keterbatasan, pemantauan $\mathrm{pH}$ esofagus ( $\mathrm{pH}$-metri) saat ini dianggap sebagai baku emas untuk mendeteksi adanya paparan asam pada esofagus, frekuensi dan lama RGE, serta hubungan gejala klinis dengan kejadian RGE. Dalam keadaan normal, $\mathrm{pH}$ esofagus adalah antara 5-7. Penurunan pH di bawah 4 merupakan petanda adanya RGE asam. 
Sari Pediatri, Vol. 8, No. 1, Juni 2006

Tabel 1. Spektrum gejala klinis esofagitis refluks

\begin{tabular}{|c|c|c|c|}
\hline Gejala & Bayi & Anak & Dewasa \\
\hline Muntah & ++ & ++ & ++ \\
\hline Regurgitasi & +++ & ++ & ++ \\
\hline Heartburn/Pyrosis & $?$ & ++ & +++ \\
\hline Nyeri epigastrium & $?$ & + & ++ \\
\hline Nyeri dada & $?$ & + & ++ \\
\hline Disfagia & $?$ & + & ++ \\
\hline Excessive crying/Iritabel & +++ & + & - \\
\hline Anemia/Melena/Hematemesis & + & + & + \\
\hline Food refusal/Feeding disturbancies/Anorexia & ++ & + & + \\
\hline Gagal tumbuh/pertumbuhan kurang & ++ & + & - \\
\hline Abnormal posturing & ++ & + & - \\
\hline Persisting hiccups & ++ & + & + \\
\hline Dental erosions/ water brush & $?$ & + & + \\
\hline Hoarseness/ globus pharyngeus & $?$ & + & + \\
\hline Batuk persisten/aspirasi (pneumonia) & + & ++ & + \\
\hline Wheezing/laringitis/masalah telinga & + & ++ & + \\
\hline Laringomalasia/stridor & + & ++ & - \\
\hline Asma kronis/sinusitis & - & ++ & + \\
\hline ALTE/SIDS/Apnu/desaturasi & + & - & - \\
\hline Bradikardia & + & $?$ & $?$ \\
\hline Masalah tidur & + & + & + \\
\hline Kualitas hidup terganggu & ++ & ++ & ++ \\
\hline Stenosis & - & $(+)$ & + \\
\hline Barrett's/adenocarcinoma & - & $(+)$ & + \\
\hline
\end{tabular}

+++ sangat sering; ++ sering; +mungkin; -absen; ?, tidak tahu (dikutip dari Salvatore S dan Vandenplas Y) ${ }^{10}$

PH esofagus abnormal ditemukan pada 90\% anak dengan esofagitis dan $42 \%$ anak tanpa esofagitis. ${ }^{20,21,25}$ Jumlah episode refluks kurang memberikan informasi dibandingkan parameter lain seperti indeks refluks (persentase total waktu saat $\mathrm{pH}$ esofagus bagian bawah <4) dan jumlah episode refluks yang berlangsung lebih dari 5 menit. ${ }^{20,21,25}$ Indeks refluks di atas 5\% merupakan petunjuk adanya RGE patologis, sedangkan indeks refluks di atas $10 \%$ harus dicurigai adanya esofagitis refluks. ${ }^{25}$

\section{Endoskopi}

Endoskopi merupakan prosedur diagnostik yang perlu dilakukan untuk melihat esofagitis. Walaupun demikian, gambaran normal mukosa esofagus pada endoskopi tidak dapat menyingkirkan esofagitis. Oleh karena itu, biopsi jaringan esofagus untuk pemeriksaan patologi anatomi diperlukan pada setiap tindakan endoskopi. Pemeriksaan patologi anatomi diperlukan untuk mendeteksi esofagitis refluks dan menyingkirkan penyebab esofagitis lainnya. ${ }^{20,21,26}$ Biopsi jaringan dilakukan dengan bantuan endoskopi pada lokasi $2 \mathrm{~cm}$ di atas SEB. Jaringan yang dibiopsi harus cukup sehingga dapat memperlihatkan ada tidaknya gambaran esofagitis. ${ }^{3}$ Berdasarkan pemeriksaan endoskopi, Savary-Miller membagi esofagitis menjadi 4 klasifikasi sesuai dengan kerusakan mukosa. Klasifikasi ini telah digunakan secara luas baik pada pasien dewasa maupun anak. ${ }^{27}$ (Tabel 2)

Klasifikasi ini mempunyai kelemahan bila diterapkan pada anak. Proses inflamasi ditegakkan hanya berdasarkan esofagitis erosif dan tidak memperhitungkan tanda inflamasi yang lebih ringan, seperti edema, hiperemis, atau kerapuhan mukosa yang sering ditemukan pada anak dan umumnya anak jarang mengalami esofagitis refluks berat. Oleh karena itu, 
beberapa peneliti mengajukan klasifikasi lain agar lebih sesuai dengan anak (Tabel 3). ${ }^{26}$

\section{Patologi anatomi}

\section{The European Society of Paediatric Gantroenterology and} Nutrition (EPSGAN) merekomendasikan penggunaan kriteria histologi untuk mendiagnosis esofagitis refluks (Tabel 4). ${ }^{27}$ Vieira dkk. dalam pengamatannya menemukan rendahnya hubungan antara gambaran endoskopi dan histologi. Beberapa anak dengan gejala klinis esofagitis refluks seringkali memperlihatkan gambaran endoskopi normal atau kelainan minimal, tetapi memperlihatkan gambaran histologi hiperplasia epitel skuamosa esofagus yang merupakan gambaran histologi awal dari esofagitis refluks. Tujuh puluh sembilan persen bayi dengan gambaran histologi esofagitis mempunyai gambaran endoskopi yang normal, sebaliknya $12 \%$ bayi dengan gambaran endoskopi esofagitis derajat 1 memperlihatkan gambaran histologi yang normal. ${ }^{26}$

Sel radang yang terdapat pada refluks esofagitis adalah eosinofil, neutrofil, dan limfosit. Eosinofil dan neutrofil tidak terdapat pada epitel esofagus anak

Tabel 2. Klasifikasi esofagitis berdasarkan pemeriksaan endoskopi (Klasifikasi Savary Miller) ${ }^{27}$

Grade Symptoms

1. Nonconfluent erosions appearing as red patches or striae just above the $Z$ line

2. Longitudinal noncircumferent erosion with a hemorrhagic tendency of the mucosa

3. Circumferent confluent longitudinal erosions with a hemorrhagis tedency; no strictures

4. A. Ulceration with sticture or metaplasia

B. Strictures without erosions or ulcerations

Tabel 3. Klasifikasi esofagitis refluks (Tygat)

\begin{tabular}{|c|c|}
\hline Grade & Symptoms \\
\hline 0 & $\begin{array}{l}\text { No evidence of reflux-induce damage, sharply delineated squamocolumnar mucosal junction } \\
\text { (SCMJ) }\end{array}$ \\
\hline 1 & $\begin{array}{l}\text { Mild, patchy, or diffuse erythema at the level of the SCMJ; minor friability; loss of shininess of the } \\
\text { distal squamous mucosa. There is no apparent break in the mucosa }\end{array}$ \\
\hline 2 & $\begin{array}{l}\text { One or more discrete superficial erosions seen as red dots or streaks with or without adherent whitish } \\
\text { exudates. }\end{array}$ \\
\hline 3 & $\begin{array}{l}\text { Confluent but non-circumferential erosions seen as defect that merge either longitudinally or laterally. } \\
\text { There may be additional exudates covering the erosive defect or slough formation. Less than } 50 \% \text { of } \\
\text { the overall mucosal surface of the distal } 5 \mathrm{~cm} \text { is involved. }\end{array}$ \\
\hline 4 & $\begin{array}{l}\text { Circumferential erosions or exudative lesion at the level of the SCMJ, regardless of the extent along } \\
\text { the distal esophagus. }\end{array}$ \\
\hline 5 & Deep ulceration anywhere along the esophagus, with various degrees of structuring \\
\hline
\end{tabular}

dikutip dari Vieira MC, Pisani JC, Mulinari RA. ${ }^{26}$

Tabel 4. Klasifikasi histologi esofagitis refluks

\begin{tabular}{lll} 
0 & Normal \\
I & A & Basal zone hyperplasia \\
& B & Elongated stromal papillae \\
& C & Vascular ingrowth \\
II & & Polymorphonuclear cell in the epithelium, lamina propria or both \\
III & Polymorphs with ephitelial defect \\
IV & Ulceration \\
V & Abnormal columnar epithelium \\
\hline
\end{tabular}

dikutip dari Vandenplas Y.27 
normal. ${ }^{23,28}$ Eosinofil memiliki nilai diagnostik esofagitis refluks. Adanya satu atau lebih eosinofil pada lamina propria merupakan indeks PRGE. Neutrofil pada epitel esofagus juga merupakan indeks spesifik, tetapi tidak sensitif untuk refluks gastroesofagus, karena hanya ditemukan pada kurang dari sepertiga pasien dengan PRGE. Limfosit terdapat dalam jumlah yang banyak pada mukosa esofagus pasien PRGE, namun merupakan komponen intraepitelial normal sehingga tidak memiliki peran untuk diagnosis. ${ }^{28}$ Hiperplasia membran basal yang terjadi mempunyai ketebalan membran basal mencapai lebih dari 15\% (20\%-25\%) dari ketebalan epitel normal dan pemanjangan papila subepitelial lebih dari 50\% sampai $75 \%$ dari ketebalan epitel normal. ${ }^{23,28}$ Apabila pada jaringan biopsi tidak terdapat lamina propria, maka cells with irregular nuclear contour (CINC) intraepitel dapat digunakan untuk diagnosis esofagitis refluks. ${ }^{29}$ Kerusakan mukosa esofagus yang melebihi proses perbaikan jaringan dapat menyebabkan infiltrasi sel radang akut, erosi dan ulserasi epitel. ${ }^{13}$ Ulkus jarang ditemukan pada anak, mungkin disebabkan oleh durasi refluks yang singkat.

\section{Terapi}

\section{Modifikasi pola hidup}

Modifikasi pola hidup dilaporkan dapat menurunkan paparan asam pada esofagus. Modifikasi pola hidup tersebut berupa meninggikan posisi kepala, punggung, dan pinggang saat tidur (membentuk sudut 45-60 derajat dengan alas tempat tidur), mengurangi asupan lemak, menghindarkan posisi berbaring terlentang selama 2-3 jam sesudah makan, dan mengurangi berat badan pada anak obes. Makanan tertentu seperti coklat, alkohol, pepermint, kopi, makanan berbumbu, dan mungkin bawang serta garlik harus dihindarkan karena dianggap meningkatkan RGE. Beberapa penulis mengasumsikan bahwa 20\%-30\% respon plasebo adalah akibat dari perubahan pola hidup, namun hal ini perlu diteliti lebih lanjut. ${ }^{17,24}$

\section{Terapi farmakologis}

\section{Prokinetik}

Prokinetik berperan pada peningkatan tekanan SEB, merangsang peristaltik esofagus, dan memperbaiki pengosongan lambung. ${ }^{23}$ Cisaprid merupakan prokinetik yang paling sering digunakan pada RGE karena mempunyai efikasi yang lebih baik dibandingkan domperidon dan metoklopramid. Cisaprid lebih efektif mengurangi RGE (berdasarkan pHmetri), memiliki onset kerja yang lebih cepat, dan ditoleransi lebih baik dibanding dengan metoklopramid. Sedangkan, domperidon dilaporkan memiliki efektifitas yang sama dengan metoklopramid. 5,10,23

Pada beberapa penelitian dilaporkan bahwa cisaprid tidak secara substansial menghilangkan gejala refluks, meskipun dapat mengurangi indeks refluks (lamanya $\mathrm{pH}$ esofagus berada di bawah 4 yang dipantau dengan pHmetri) dan meningkatkan klirens esofagus melalui peningkatan sekresi saliva. Cisaprid juga dapat membantu menyembuhkan esofagitis., ${ }^{5,10,30}$

Tidak seperti metoklopramid, cisaprid memberikan efek samping serius yang sangat kecil. Beberapa keluhan pernah disampaikan oleh pasien yang mendapat cisaprid, antara lain kram perut ringan, diare atau konstipasi. Efek samping serius pada jantung tidak pernah dilaporkan pada bayi atau anak yang mendapat cisaprid dengan dosis yang direkomendsikan $(0,8 \mathrm{mg} / \mathrm{kg} /$ hari, maksimal $40 \mathrm{mg} /$ hari). ${ }^{5,17}$ Oleh karena adanya laporan efek samping serius pada orangtua yang menggunakan cisaprid, maka pengadaan obat tersebut saat ini dibatasi hanya pada rumah sakit. Walaupun demikian, penggunaan cisaprid pada bayi dan anak belum dihilangkan dari rekomendasi tata laksana RGE pada anak. ${ }^{5}$

\section{Antagonis reseptor $\mathrm{H} 2$}

Antagonis reseptor $\mathrm{H} 2$ (cimetidin, ranitidin, famotidin, $\mathrm{dsb}$ ) dapat menurunkan sekresi asam lambung dengan menghambat reseptor histamin-2 pada sel parietal lambung. Antagonis reseptor H2 (ARH2) cukup efektif dalam menyembuhkan esofagitis pada bayi dan anak. Beberapa penelitian menunjukan penurunan indeks refluks pada pemberian ranitidin. Penggunaan famotidin pada anak masih sangat terbatas.

Antagonis reseptor $\mathrm{H} 2$ dapat digunakan sebagai terapi pemeliharaan pada esofagitis refluks. Kombinasi dengan prokinetik akan memberikan efek yang lebih baik dibanding dengan pemberian hanya ARH2. Pemberian ranitidin saja memberikan remisi $49 \%$, sedangkan pemberian ranitidin dengan cisaprid memberikan remisi 66\%. ${ }^{24,31}$ Untuk pasien yang refrakter sebaiknya diberikan tambahan terapi lain atau digunakan penghambat sekresi asam lambung yang lebih poten seperti IPP. ${ }^{17}$ 


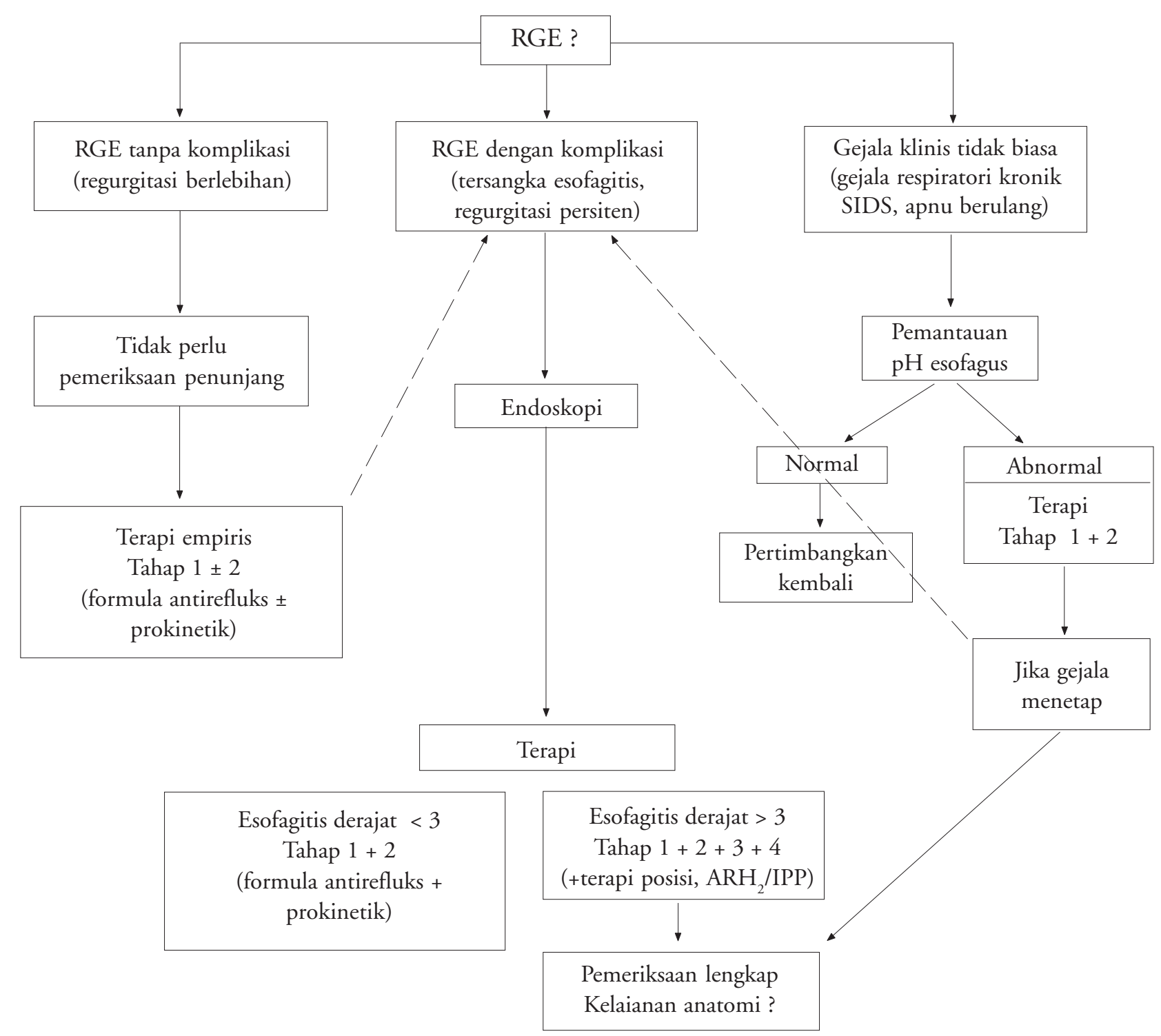

Tahap 1 : parental reassurance + thickening milk

Tahap 2 : prokinetik

Tahap 3 : posisi tubuh saat tidur

Tahap 4 : antagonis reseptor H2 / IPP

Tahap 5 : operasi

Gambar 1. Algoritme pendekatan tata laksana RGE pada anak (dikutip dari Vandenplas Y dan Hegar B). ${ }^{5}$

\section{Inhibitor pompa proton}

Inhibitor pompa proton (omeprazol, esomeprazol, lansoprazol, pantoprazol, rabeprazol) merupakan obat pilihan pada esofagitis refluks. Pada orang dewasa, efikasi terapi jangka pendek, jangka panjang, serta pencegahan relaps esofagitis dari IPP lebih baik dibanding ARH2., 323,24

Omeprazol merupakan IPP yang sering diteliti penggunaannya pada anak. Pengamatan yang dilakukan oleh Zimmermann dkk. menunjukan dosis omeprazol $1 \mathrm{mg} / \mathrm{kgBB} /$ hari efektif untuk 
penyembuhan esofagitis dan menghilangkan gejala klinis. ${ }^{32}$ Omeprazol diberikan 1 kali per hari pada pagi hari, saat atau sebelum sarapan.,33 Omeprazol efektif pada lebih dari 90\% anak dengan esofagitis refluks kronis yang resisten terhadap terapi prokinetik dan ARH $2 .^{3}$

Pengamatan yang dilakukan Karjoo dan Kane terhadap 129 anak dengan esofagitis refluks didapatkan $70 \%$ anak respon terhadap terapi ranitidin dosis tinggi ( $4 \mathrm{mg} / \mathrm{kg} /$ dosis, 2-3 kali/hari) selama 8 minggu. Dari $30 \%$ anak yang tidak respon terhadap terapi ranitidin, $87 \%$ diantaranya respon terhadap omeprazol $(20 \mathrm{mg} /$ hari) selama 8 minggu. ${ }^{34}$ Sembilan puluh persen anak dengan esofagitis derajat 1 respon terhadap ranitidin dan hanya $43 \%$ anak dengan esofagitis derajat 3 atau 4 yang respon terhadap ranitidin. Pemberian omeprazol saja atau kombinasi dengan cisaprid memberikan hasil yang lebih efektif dibandingkan pemberian ranitidin saja, ataupun cisaprid saja, ataupun kombinasi ranitidin dan cisaprid. ${ }^{31}$ Laporan penggunaan esomeprazol, lansoprazol, pantoprazol, dan rabeprazol pada anak masih sangat terbatas. ${ }^{33,35}$ Pengamatan terus menerus selama 9 tahun terhadap anak yang mendapat omeprazol tidak memperlihatkan efek samping selain hiperplasia sel parietal pada beberapa anak dan polip kelenjar fundus benigna pada 2 kasus. ${ }^{33}$

\section{Antasid}

Antasid berfungsi untuk menetralisir asam lambung sehingga dapat mengurangi paparan asam terhadap esofagus dan mengurangi gejala heartburn. Penggunaan antasid dosis tinggi (magnesium hidroksida dan aluminium hidroksida; $700 \mathrm{mmol} / 1,73 \mathrm{~m} 2 /$ hari) sama efektifnya dengan terapi cimetidin untuk esofagitis pada anak usia 2-42 bulan. ${ }^{23}$ Pemberian antasid pada anak hanya dianjurkan untuk jangka pendek, tidak untuk terapi jangka panjang karena peningkatan kadar aluminium plasma dapat menyebabkan osteopeni, anemia mikrositik dan neurotoksik. ${ }^{23}$

\section{Operasi antirefluks}

Tindakan operasi sering dipertimbangkan pada PRGE yang resisten terhadap terapi medis atau yang tidak bersedia menerima terapi medis untuk jangka panjang. ${ }^{23,36}$ Nissen fundoplication merupakan prosedur operasi antirefluks yang umumnya di- kerjakan pada anak. Operasi ini dapat dilakukan melalui laparoskopik atau operasi terbuka. Meskipun tidak ada perbedaan hasil maupun komplikasi dari keduanya, laparoskopi memerlukan biaya lebih murah dan rawat inap lebih singkat secara bermakna. . $3,24,36^{2}$

Risiko, keuntungan, biaya dan kesuksesan terapi medis jangka panjang dibandingkan operasi belum diteliti secara rinci. Satu penelitian yang membandingkan terapi omeprazol dengan operasi menunjukan hasil yang sama bila omeprazol diberikan 40-60 mg/ hari. $^{24}$

Untuk mempermudah tata laksana RGE, telah dibuat algoritme pendekatan tata laksana RGE pada anak. ${ }^{5}$ (Gambar 1)

\section{Kesimpulan}

Esofagitis refluks merupakan salah satu masalah saluran cerna pada anak yang perlu mendapat perhatian. Pemahaman gejala klinis, pemilihan pemeriksaan penunjang, dan pemberian terapi yang adekuat sangat diperlukan untuk memberikan kualitas hidup anak yang optimal. Untuk menunjang hal tersebut telah dibuat kesepakatan tentang pendekatan tata laksana refluks RGE pada anak.

\section{Daftar Pustaka}

1. Chu AS. Esophagitis. Diunduh dari www.emedicine. com, diakses tanggal 9 September 2004.

2. Orlando RC. Reflux esophagitis. Dalam: Yamada T, penyunting. Textbook of gastroenterology. Edisi ke-2. Philadelphia: Lippincott Company; 1995. h. 1214-41.

3. Vanderplas Y, Hegar B. Esophagitis ini children. Dalam: Trihono PP, Pudjiarto PS, Syarif DR, Hegar B, Gunardi $\mathrm{H}$, Oswari $\mathrm{H}$, dkk, penyunting. Hot topics in pediatrics II. Jakarta: Balai Penerbit FKUI;2002. h. 74-83.

4. Hegar B, Rastra. Pendekatan tata laksana refluks gastroesofagus pada anak. Maj Kedokt Indon 2004; 54: 325-31.

5. Vandenplas Y, Hegar B. Diagnosis and treatment of gastro-oesophageal reflux disease in infants and children. J Gastroenterol Hepatol 2000;15:593-603.

6. Gold BD. Gastroesophageal reflux disease: could intervention in childhood reduce the risk of later complications? Am J Med 2004;117:23S-7S. 
7. Hegar B, Boediarso A, Firmansyah A, Vandenplas Y. Investigation of regurgitation and other symptoms of gastroesophageal reflux in Indonesian infans. World J Gastroenterol 2004;10:1795-7.

8. Nelson SP, Chen EH, Syniar GM, Christoffel KK. Prevalence of symptoms of gastroesophageal reflux during infancy. Arc Pediatr Adolesc Med 1997;151:569-72.

9. Nelson SP, Chen EH, Syniar GM, Christoffel KK. Oneyear follow-up of symptoms of gastroesophageal reflux during infancy. Pediatrics 1998;102:1-4.

10. Salvatore S, Vandenplas Y. Gastro-oesophageal reflux disease and motility disorders. Best Practice\&Research Clin Gastroenterol 2003;17:163-79.

11. El-Serag HB, Bailey NR, Gilger M, Rabeneck L. Endoscopic manifestations of gastroesophageal reflux disease in patiens between 18 months and 25 years without neurological deficits. Am J Gastroenterol 2002;97:1635-9.

12. Nelson SP, Chen EH, Syniar GM, Christoffel KK. Prevalence of symptoms of gastroesophageal reflux during childhood. Arc Pediatr Adolesc Med 2000;154:150-4.

13. Hamilton SR. Reflux esophagitis and barrett esofagus. Dalam: Goldman H, Appelman HD, Kaufman N, penyunting. Gastrointestinal pathology. Baltimore: Williams \& Wilkins;1990. h. 11-29.

14. Hogan WJ, Dodds WJ. Gastroesophageal reflux disease (reflux esophagitis). Dalam: Wickland E, penyunting. Gastrointestinal disease. Edisi ke-4. Philadelphia: WB Saunders;1989. h. 594-616.

15. Mittal RK. Pathophysiology of gastroesophageal reflux: motility factors. J Gastroenterol 2003;38:7-12.

16. Davidson GP, Omari TI. Pathophysiological mechanisms of gastroesophageal reflux disease in children. Gastroenterology 2001;3:257-62.

17. Spechler SJ. Gastroesophageal reflux disease and its complications. Dalam: Grendell JH, McQuaid KR, Friedman SL, penyunting. Current diagnosis and treatment in gastroenterology. USA: Appleton and Lange; 1996. h. 245-60.

18. Yoshida N, Yoshikawa T. Defense mechanism of the esophageal mucosa and esophageal inflammation. J Gastroenterol 2003;38:31-4.

19. Orel R, Marcovic S. Bile in the esophagus: a factor in the pathogenesis of reflux esophagitis in children. J Ped Gastroenterol Nutr 2003;36:172-4.

20. Hegar B, Firmansyah A. Diagnosis refluks gastroesofagus pada anak. Maj Kedokt Indon 1999;49:70-4.

21. Aw M. Pediatric gastro-oesophageal reflux disease (GERD). A relook at a common problem. National university hospital. MITA 2003;34:1-14.
22. Sunku B, Marino RV, Sockolow R. A primary care approach to pediatric gastroesophageal reflux. JOAO 2002;100:S11-S15.

23. Rudolph CD, Mazur LJ, Liptak GS, Baker RD, Boyle JT, Colletti RB, dkk. Guidelines for evaluation and treatment of gastroesophageal reflux in infants and children: Recommendations for the north american society for pediatric gastroenterologi and nutrition. J Pediatr Gastroentrol Nutr 2001;32:S1-S31.

24. DeVault KR, Castell DO. Update guidelines for diagnosis and treatment of gastroesophageal reflux disease. Am j Gastroenterol 1999; 94:1434-42.

25. Hegar B, Vandenplas Y. Gastro-oesophageal reflux ini infancy. J Gastroenterol Hepatol 1999;14:13-9.

26. Vieira MC, Pisani JC, Mulinari RA. Diagnosis of reflux esophagitis in infants: histology of the distal esophagus must complement upper gastrointestinal endoscopy. J de Pediatria 2004; 80:197-202.

27. Vandenplas Y. Reflux esophagitis in infants and children: a report from the Working Group on Gastroesophageal Reflux Disease of the European Society of Paediatric Gastroenterology and Nutrition. J Pediatr Gastroenterol Nutr 1994;18:413-22.

28. Bronner MP. Inflammatory disorders of the esophagus. Didapat dari www.google.com. Diakses tanggal 9 Desember 2004.

29. Esposito S, Valente G, Zavallone A, Guidali P, Rapa A, Oderda G. Histological score for cells with irregular nuclear contour for the diagnosis of reflux esophagitis in children. Human Pathology 2004;35:96-100.

30. Cohen RC, O'Loughlin EV, Davidson GP, Moore DJ, Lawrence DM. Cisapride in the control of symptoms in infants with gastroesophageal reflux: a randomized, doubleblind, placebo-controlled trial. J Pediatr 1999;134:287-92.

31. Vigneri S, Termini R, Leandro G, Badalamenti S, Pantalena M, Savarino V, dkk. A comparison of five maintenance therapies for reflux esophagitis. N Engl J Med 1995;333:1106-10.

32. Zimmermann AE, Walters JK, Katona BG, Souney PF, Levine D. A review of omeprazole use in the treatment of acid-related disorders in children. Clin Ther 2001; 23:660-79.

33. Israel DM, Hassall E. Omeprazol and other proton inhibitors:pharmacology, efficacy and safety, with special reference to use in children. J Pediatr Gastroenterol Nutr 1998;27:568-79.

34. Karjoo M, Kane R. Omeprazol treatment of children with peptic esophagitis refractory to ranitidine therapy. Arch Pediatr Adolesc Med 1995;149:267-71. 
Sari Pediatri, Vol. 8, No. 1, Juni 2006

35. Madrazo-de la Garza A, Dibildox M, Vargas A, Delgado J, Gonzalez J, Yanez P. Efficacy and safety of oral pantoprazol $20 \mathrm{mg}$ given once daily for reflux esophagitis in children. J Pediatr Gastroenterol Nutr 2003;36: 261-5.
36. Christensen ML, Gold BD. Clinical management of infant and children with gastroesophageal reflux disease : disease recognition and therapeutic options. ASHP Midyear Clinical Meeting: 9 Desember 2002; Atlanta, Georgia; 2002. h. 1-11. 